$B J M G 11 / 2(2008) 11-16$

$10.2478 / \mathrm{v} 10034-008-0022-0$

ORIGINAL ARTICLE

\title{
THE TNF $\alpha$ GENE G(-308)A POLYMORPHISM AS A MARKER FOR MYOCARDIAL INFARCTION IN TYPE 2 DIABETES MELLITUS
}

\author{
Reschner $\mathrm{H}^{1 * *}$, Steblovnik $\mathrm{K}^{2 * *}$, Milutinović $\mathrm{A}^{2}$, Petrovič $\mathrm{D},{ }^{2 *}$
}

\begin{abstract}
*Corresponding Author: Professor Dr. Danijel Petrovič, Institute of Histology and Embryology, Medical Faculty, University of Ljubljana, Korytkova 2, Ljubljana 1000, Slovenia; Tel.: +386-1543-73-67; Fax: +386-1-543-73-61; e-mail: Daniel.Petrovic@mf.uni-lj.si
\end{abstract}

\begin{abstract}
Type-2 diabetes mellitus (DM2) is a major risk factor for the development of coronary artery disease (CAD) and subsequent myocardial infarction (MI). Because the pro-inflammatory cytokine tumor necrosis factor $\alpha$ (TNF $\alpha)$ takes part in several stages of the development of atherosclerosis, we investigated the association of the TNF $\alpha$ gene $\mathrm{G}(-308) \mathrm{A}$ polymorphism with MI in 142 DM2 patients and in 310 patients who had had DM2 for over 10 years with no clinical signs of CAD and measured the serum TNF $\alpha$ levels in 70 consecutive DM2 patients: 10 with MI and 60 without MI.

We found no association between the $\mathrm{G}(-308) \mathrm{A}$ polymorphism and $\mathrm{MI}$ in DM2 [odds ratio $(\mathrm{OR})=$ $0.8,95 \%$ confidence interval $(\mathrm{CI})=0.5-1.3, p=0.4$ for the recessive model and $\mathrm{OR}=0.8,95 \% \mathrm{CI}=0.2$ $2.8, p=0.7$ for the dominant model]. Significantly higher TNF $\alpha$ serum levels were found in 58 DM2 patients with the GG genotype compared to 12 with the AG genotype $(1.13 \pm 0.6 \mathrm{ng} / \mathrm{L} v s .0 .53 \pm 0.35$ $\mathrm{ng} / \mathrm{L}, p<0.01)$. We concluded that the TNF $\alpha$ gene $\mathrm{G}(-308)$ A polymorphism is not a risk factor for MI with DM2 in Slovenes of Slavic origin.
\end{abstract}

1 Zdravstveni Zavod Reschner, Ljubljana 1000,

Slovenia

2 Institute of Histology and Embryology, Medical Faculty, University of Ljubljana, Ljubljana 1000, Slovenia

** H. Reschner and K. Steblovnik K contributed equally to this study.
Key words: Type 2 diabetes mellitus (DM2); Coronary artery disease (CAD); Myocardial infarction (MI); Tumor necrosis factor $\alpha(\mathrm{TNF} \alpha)$ gene $\mathrm{G}(-308)$ A polymorphism.

\section{INTRODUCTION}

Coronary artery disease (CAD) is the leading cause of death in the European Union and in the rest of the developed world [1,2]. Atherosclerosis is generally accepted as a chronic inflammatory condition [3] and growing evidence indicates an important role of chronic inflammation in type 2 diabetes mellitus (DM2) [4]. The pro-inflammatory cytokines may play a central role in the pathogenesis of both CAD and DM2 [3]. An important pro-inflammatory cytokine is tumor necrosis factor $\alpha(\mathrm{TNF} \alpha)$ promotes inflammation and signals leading to cell death. It is produced by macrophages, mastocytes, lymphocytes, endothelial cells, and adipocytes [5]. With interleukins (IL) 1 and 6 it has a key role in inflammatory and immune reactions [6]. The TNF plasma concentrations increase in patients affected with premature CAD and is involved in obesity and insulin resistance [7-9], and its expression is regulated at the transcriptional level [10].

The TNF $\alpha$ gene is located on the short arm of chromosome 6 (p21.1-21.3) between the class I and class II regions of the HLA complex. A polymorphism that affects its transcription has been identified in the promoter region of the gene, a guanineto-adenosine transition at $-308 \mathrm{bp}$ in the promoter 
region (termed the A allele). In some studies but not in others, an association between this polymorphism and CAD was demonstrated [12-16]. Since this polymorphism has not been tested as a potential marker of MI in DM2, we investigated whether it is associated with increased serum levels of $\mathrm{TNF} \alpha$, and whether it is associated with increased risk for MI in patients.

\section{PATIENTS AND METHODS}

We studied Slovene patients of Slavic origin from independent families who had DM2 lasting more than 10 years: 142 with MI (MI group) and 310 DM2 patients with no history of CAD, and no signs of ischemic changes on electrocardiogram and no ischemic changes during submaximal stress testing [17]. The diagnosis of MI was based on the World Health Organization criteria [18]. Patients with MI were included in the study 1-9 months after the acute event. After informed consent was obtained from the patients and control subjects, we conducted a detailed interview. Arterial hypertension and cigarette smoking were defined as binary variables. Patients were classified as having DM2 according to the American Diabetes Association criteria for the diagnosis and classification of diabetes [7]. Body mass index (BMI) was calculated as weight in kilograms divided by the height in square meters. Total serum cholesterol, low density lipoprotein (LDL) cholestetol, high density lipoprotein (HDL) cholesterol and triglycerides serum levels were determined by standard biochemical methods. We analyzed serum TNF $\alpha$ levels in a subpopulation of 70 consecutive DM2 patients: 10 with MI and 60 without MI; in this group there were eight smokers and 62 non smokers, and the mean age was $62.5 \pm 10.9$ years.

The G(-308)A polymorphism was evaluated by polymerase chain reaction (PCR) using the following primers: sense (5'-AGG CAA TAG GTT TTG AGG GCC AT-3'), antisense (5'-TCC TCC CTG CTC CGA TTC CG-3'). The cycling conditions were: two cycles at $94^{\circ} \mathrm{C}$ for 3 min., $60^{\circ} \mathrm{C}$ for 1 min., $72^{\circ} \mathrm{C}$ for $1 \mathrm{~min}$.; 35 cycles at $94^{\circ} \mathrm{C}$ for $1 \mathrm{~min}$., $60^{\circ} \mathrm{C}$ for $1 \mathrm{~min} ., 2^{\circ} \mathrm{C}$ for $1 \mathrm{~min}$.; two cycles at $94^{\circ} \mathrm{C}$ for $1 \mathrm{~min}$., $60^{\circ} \mathrm{C}$ for $1 \mathrm{~min}$. and $72^{\circ} \mathrm{C}$ for $5 \mathrm{~min}$. The PCR product of $107 \mathrm{bp}$ was digested with the NcoI restriction enzyme (Fermentas, St. Leon-Rot, Austria) into two fragments of 87 and $20 \mathrm{bp}$, respec- tively. The products of 87 and $20 \mathrm{bp}$ represented the $\mathrm{G}$ allele, whereas undigested PCR products represented the A allele. The products were separated by electrophoresis on a $2 \%$ agarose gel and visualized by ethidium bromide staining [19]. Two of us (KS, $\mathrm{DP}$ ), who were blinded for the origin of the DNA sample, performed the genotype classification.

Differences in mean values were analyzed by the Student $t$-test. The chi-square test was used to compare discrete variables and genotype distributions. Genotypic odds ratios (ORs) for MI with 95\% confidence intervals (CIs) with two-tailed $p$ values were calculated by the chi-square test. Statistical analysis was performed using the SPSS program 15 for Windows (SPSS Inc., Chicago, IL, USA).

\section{RESULTS}

The characteristics of the patients studied are summarized in Table 1. The patients with MI were younger, predominantly male and had a higher incidence of cigarette smoking than those without MI. They also had higher total cholesterol and LDL cholesterol levels, and longer duration of DM2 (Table 1). There were no significant differences in the incidence of hypertension, HDL cholesterol and triglyceride levels between the two groups (Table 1).

The frequency of the G(-308)A polymorphism is shown in Table 2. These were compatible with the Hardy-Weinberg expectations. There was no association between the polymorphism and $\mathrm{MI}$ in $\mathrm{DM} 2$ patients $(\mathrm{OR}=0.8,95 \% \mathrm{CI}=0.5-1.3, p=$ 0.4 for the recessive model and $\mathrm{OR}=0.8,95 \% \mathrm{CI}$ $=0.2-2.8, \mathrm{p}=0.7$ for the dominant model). The allele frequencies in patients with MI were: G 247 (87.0\%) and A 37 (13.0\%), and allele frequencies in patients without MI were: G 550 (88.7\%) and A $70(11.3 \%)$; the difference was not statistically significant.

We analyzed serum TNF $\alpha$ levels in 70 consecutive DM2 patients. Significantly higher levels were found in 58 patients with the GG genotype compared to 12 patients with the $\mathrm{AG}$ genotype $(1.13 \pm 0.6 \mathrm{ng} / \mathrm{L}$ vs. $0.53 \pm 0.35 \mathrm{ng} / \mathrm{L}$ : $p<0.01)$. We found no statistically significant differences between $10 \mathrm{DM} 2$ patients with MI and 60 DM2 patients without MI $[0.61 \pm 0.528 \mathrm{ng} / \mathrm{L}$ vs. $1.10 \pm 1.23 \mathrm{ng} / \mathrm{L}, p=$ no significance (n.s.)]. Moreover, we failed to demonstrate statistically 
Table 1. Characteristics of patients with type 2 diabetes mellitus

\begin{tabular}{|l|c|c|c|c|c|}
\hline Parameters & $\begin{array}{c}\text { DM2 With } \\
\text { MI }\end{array}$ & $\begin{array}{c}\text { DM2 } \\
\text { Without MI }\end{array}$ & \% & $\boldsymbol{p}$ Value \\
\hline Number of patients & 142 & & 310 & & \\
\hline Age [in years \pm standard deviation (SD)] & $61.0 \pm 11.9$ & & $66.2 \pm 9.8$ & & $<0.001$ \\
\hline Males & 95 & 66.9 & 144 & 46.4 & $<0.001$ \\
\hline Females & 47 & 33.1 & 166 & 53.6 & $<0.001$ \\
\hline Body mass index $\left(\mathrm{kg} / \mathrm{m}^{2} \pm \mathrm{SD}\right)$ & $28.7 \pm 3.9$ & & $29.0 \pm 4.6$ & & 0.4 \\
\hline Arterial hypertension & 100 & 70.4 & 219 & 70.6 & 0.8 \\
\hline Normotensive DM2 patients & 42 & 29.6 & 91 & 29.4 & 0.9 \\
\hline Systolic BP (mm Hg $\pm \mathrm{SD})$ & $147 \pm 21$ & & $143 \pm 22$ & & 0.1 \\
\hline Diastolic BP $(\mathrm{mm} \mathrm{Hg} \pm \mathrm{SD})$ & $83 \pm 10$ & & $84 \pm 10$ & & 0.5 \\
\hline Smoking habit & 58 & 40.8 & 37 & 11.9 & $<0.001$ \\
\hline DM2 duration $($ years $\pm \mathrm{SD})$ & $21.7 \pm 7.7$ & & $17.9 \pm 8.0$ & & 0.001 \\
\hline Total serum cholesterol (mmol/L $\pm \mathrm{SD})$ & $5.7 \pm 1.6$ & & $5.3 \pm 1.3$ & & 0.01 \\
\hline HDL serum cholesterol (mmol/L $\pm \mathrm{SD})$ & $1.1 \pm 0.3$ & & $1.2 \pm 0.4$ & & 0.12 \\
\hline LDL serum cholesterol (mmol/L $\pm \mathrm{SD})$ & $3.6 \pm 1.5$ & & $3.2 \pm 1.0$ & & 0.001 \\
\hline Serum triglyceride $(\mathrm{mmol} / \mathrm{L} \pm \mathrm{SD})$ & $2.3 \pm 1.3$ & & $2.4 \pm 1.6$ & & 0.8 \\
\hline
\end{tabular}

Table 2. Genotype and allele distribution of the TNF $\alpha$ gene polymorphism in type 2 diabetes mellitus patients with myocardial infarction and patients without myocardial infarction

\begin{tabular}{|l|c|r|c|c|c|c|c|}
\hline TNF $\alpha$ Genotype & $\begin{array}{c}\text { DM2 } \\
\text { With MI }\end{array}$ & $\begin{array}{c}\text { DM2 } \\
\text { Without } \\
\text { MI }\end{array}$ & \% & OR & $\mathbf{9 5 \%}$ CI & $\boldsymbol{p}$ Value \\
\hline Genotype GG & 109 & 76.8 & 247 & 79.7 & 0.8 & $0.5-1.3^{\mathrm{a}}$ & $0.4^{\mathrm{a}}$ \\
\hline Genotype GA & 29 & 20.4 & 56 & 18.1 & 0.8 & $0.2-2.8^{\mathrm{b}}$ & $0.7^{\mathrm{b}}$ \\
\hline Genotype AA & 4 & 2.8 & 7 & 2.2 & & & \\
\hline Total & 142 & 100.0 & 310 & 100.0 & & & \\
\hline G allele & 247 & 87.0 & 550 & 88.7 & & & 0.5 \\
\hline A allele & 37 & 13.0 & 70 & 11.3 & & & \\
\hline Total & 284 & 100.0 & 620 & 100.0 & & & \\
\hline
\end{tabular}

${ }^{a} p$ Value and OR for recessive model (TNFa: AA vs. GA plus GG).

${ }^{\mathrm{b}} p$ Value and OR for dominant model (TNFa: AA plus GA vs. GG). 
significant differences in serum TNF $\alpha$ levels between eight smokers and 62 non smokers (1.35 $\pm 0.8 \mathrm{ng} / \mathrm{L} v s .1 .11 \pm 1.22 \mathrm{ng} / \mathrm{L}, p=$ n.s.). Similarly, no statistically significant correlation between age and serum TNF $\alpha$ levels were demonstrated ( $p=0.9$, correlation coefficient $=0.004$ ).

\section{DISCUSSION}

We found no association between the TNF $\alpha$ gene $\mathrm{G}(-308)$ A polymorphism and MI in our Slovene patients with DM2. This may be the first report of this negative association. The G(-308)A polymorphism has been related to MI [13], to unstable angina [16], and ST-elevation MI (STEMI) [20]. Other studies failed to demonstrate an association between this polymorphism and MI $[12,14,15]$. This discordance may be due to the multifactorial nature of the MI, to differences in study design or to genetic heterogeneity within and between the populations studied. Moreover, we found significantly higher serum TNF $\alpha$ levels in DM2 patients with the GG genotype than with AG genotype. Several environmental and genetical factors (i.e., age, cigarette smoking, ischemia) influence serum TNF $\alpha$ levels $[9,21,22]$. The $\mathrm{G}(-308) \mathrm{A}$ polymorphism is most probably a functional polymorphism, since it has been reported to affect the serum TNF $\alpha$ levels $[21,22]$. The A allele was associated with decreased $\mathrm{TNF} \alpha$ concentrations in offspring less than 18 years of age and males who were not overweight [BMI $<25 \mathrm{~kg} / \mathrm{m}$ (2)]. Moreover, cigarette smoking was reported to lower TNF concentrations, but in our study we did not find an effect of smoking on TNF concentration. It has been speculated that cigarette smoking abolishes TNF $\alpha$ cellular release from cells $[21,22]$.

We studied only DM2 patients who had experienced a MI 1-9 months earlier, and our results may be affected by survival bias. Moreover, the exclusion of CAD on the basis of a negative history of MI or angina pectoris, and absence of ischemic changes on electrocardiograms and during exercise stress testing, was disadvantaged by the possibility that some of the patients without MI may have experienced asymptomatic CAD. In a recent study, $18 \%$ of asymptomatic DM2 patients with a negative result of exercise stress testing, presented silent CAD with significant $(\geq 70 \%)$ angiographically-documented coronary stenosis [17]. In conclusion, the G(-308)A polymorphism of the TNF $\alpha$ gene is not a risk factor for MI with DM2 in Slovenes of Slavic origin.

\section{REFERENCES}

1. Rosamond W, Flegal K, Friday G, Furie K, Go A, Greenlund K, Haase N, Ho M, Howard V, Kissela B, Kittner S, Lloyd-Jones D, McDermott M, Meigs J, Moy C, Nichol G, O’Donnell CJ, Roger V, Rumsfeld J, Sorlie P, Steinberger J, Thom T, Wasserthiel-Smoller S, Hong Y, American Heart Association Statistics Committee and Stroke Statistics Subcommittee. Heart disease and stroke statistics 2007 update. Circulation 2007; 115(5): 69-171.

2. Allender S, Peto V, Scarborough P, Boxer A, Rayner M. Coronary Heart Disease Statistics. London: British Heart Foundation, 2007.

3 . Ross R. Atherosclerosis-an inflammatory disease. N Engl J Med 1999; 340(2): 115-126.

4. Festa A, D'Agostino R, Tracy RP, Haffner SM. Insulin resistance atherosclerosis study. Elevated levels of acute-phase proteins and plasminogen activator inhibitor- 1 predict the development of type 2 diabetes: the insulin resistance atherosclerosis study. Diabetes 2002; 51(4): 1131-1137.

5. Walker D, Jason J, Wallace K, Slaughter J, Whatley V, Han A, Nwanyanwu OC, Kazembe PN, Dobbie H, Archibald L, Jarvis WR. Spontaneous cytokine production and its effect on induced production. Clin Diagn Lab Immunol 2002; 9(5): 10491056.

6. McMurray J, Abdullah I, Dargie HJ, Shapiro D. Increased concentrations of tumour necrosis factor in "cachectic" patients with severe chronic heart failure. Br Heart J 1991; 66(5): 356-358.

7. Hotamisligil GS, Shargill NS, Spiegelman $B M$. Adipose expression of tumor necrosis factor- $\alpha$ : direct role in obesity-linked insulin resistance. Science 1993; 259(5091): 87-91.

8. Hotamisligil GS, Spiegelman BM. Tumor necrosis factor $\alpha$ : a key component of the obesitydiabetes link. Diabetes 1994; 43(11): 1271-1278.

9. Jovinge S, Hamsten A, Tornvall P, Proudler A, Båvenholm P, Ericsson CG, Godsland I, de Faire U, Nilsson J. Evidence for a role of tumor necrosis factor $\alpha$ in disturbances of triglyceride and glucose metabolism predisposing to coronary heart disease. Metabolism 1998; 47(1): 113-118. 
10. Raabe T, Bukrinsky M, Currie RA. Relative contribution of transcription and translation to the induction of tumor necrosis factor- $\alpha$ by lipopolysaccharide. J Biol Chem 1998; 273(2): 974980.

11. Wilson AG, Symons JA, McDowell TL, McDevitt HO, Duff GW. Effects of a polymorphism in the human tumor necrosis factor $\alpha$ promoter on transcriptional activation. Proc Natl Acad Sci USA 1997; 94(7): 3195-3199.

12. Herrmann SM, Ricard S, Nicaud V, Mallet C, Arveiler D, Evans A, Ruidavets JB, Luc G, Bara L, Parra HJ, Poirier O, Cambien F. Polymorphisms of the tumour necrosis factor- $\alpha$ gene, coronary heart disease and obesity. Eur J Clin Invest 1998; 28(1): 59-66.

13. Padovani JC, Pazin-Filho A, Simões MV, Marin-Neto JA, Zago MA, Franco RF. Gene polymorphisms in the TNF locus and the risk of myocardial infarction. Thromb Res 2000; 100(4): 263269.

14. Keso T, Perola M, Laippala P, Ilveskoski E, Kunnas TA, Mikkelsson J, Penttilä A, Hurme M, Karhunen PJ. Polymorphisms within the tumor necrosis factor locus and prevalence of coronary artery disease in middle-aged men. Atherosclerosis 2001; 154(3): 691-697.

15. Koch W, Kastrati A, Böttiger C, Mehilli J, von Beckerath N, Schömig A. Interleukin-10 and tumor necrosis factor gene polymorphisms and risk of coronary artery disease and myocardial infarction. Atherosclerosis 2001; 159(1): 137-144.

16. Bernard V, Pillois X, Dubus I, Benchimol D, Labouyrie JP, Couffinhal T, Coste P, Bonnet J. The $-308 \mathrm{G} / \mathrm{A}$ tumor necrosis factor- $\alpha$ gene dimorphism: a risk factor for unstable angina. Clin Chem Lab Med 2003; 41(4): 511-516.
17. Bacci S, Villella M, Villella A, Langialonga T, Grilli M, Rauseo A, Mastroianno S, De Cosmo S, Fanelli R, Trischitta V. Screening for silent myocardial ischaemia in type 2 diabetic patients with additional atherogenic risk factors: applicability and accuracy of the exercise stress test. Eur J Endocrinol 2002; 147(5): 649-654.

18. Alpert JS, Thygesen K, Antman E, Bassand JP. Myocardial infarction redefined-a consensus document of The Joint European Society of Cardiology/American College of Cardiology Committee for the Redefinition of Myocardial Infarction. J Am Coll Cardiol 2000; 36(3): 959-969.

19. Cabrera M, Shaw MA, Sharples C, Williams H, Castes M, Convit J, Blackwell JM. Polymorphism in tumor necrosis factor genes associated with mucocutaneous leishmaniasis. J Exp Med 1995; 182(5): 1259-1264.

20. Antonicelli R, Olivieri F, Cavallone L, Spazzafumo L, Bonafè M, Marchegiani F, Cardelli M, Galeazzi R, Giovagnetti S, Perna GP, Franceschi C. Tumor necrosis factor- $\alpha$ gene $-308 \mathrm{G}>\mathrm{A}$ polymorphism is associated with ST-elevation myocardial infarction and with high plasma levels of biochemical ischemia markers. Coron Artery Dis 2005; 16(8): 489-493.

21. Vayssier M, Favatier F, Pinot F, Bachelet M, Polla BS. Tobacco smoke induces coordinate activation of HSF and inhibition of NFK in human monocytes: effects on TNF $\alpha$ release. Biochem Biophys Res Commun 1998; 252(1): 249-256.

22. Haddy N, Sass C, Maumus S, Marie B, Droesch S, Siest G, Lambert D, Visvikis S. Biological variations, genetic polymorphisms and familial resemblance of TNF- $\alpha$ and IL- 6 concentrations: STANISLAS cohort. Eur J Hum Genet 2005; 13(1): 109-117. 